\title{
Persontilpasset medisin som helsehjelp etter pasient- og brukerrettighetsloven
}

Av Anne Kjersti Befring

Artikkelen undersøker om persontilpasset medisin som inkluderer helseforskning og involverer annet personell enn de som tradisjonelt anses som helsepersonell, kan anses som helsehjelp etter pasient- og brukerrettighetsloven $\S 1-3 \mathrm{c}$. Persontilpasset medisin tar utgangspunkt $\mathrm{i}$ unders $\emptyset$ kelser av pasientens biologi (genetikk) for å kunne stille en mer presis diagnose enn det som er mulig med ordinær diagnostikk, og som den medisinske behandlingen kan tilpasses etter. Pasientforløpet inkluderer helseforskning (klinisk utprøvning) og innebærer at hjelpen gis av yrkesgrupper som ikke tradisjonelt regnes som helsepersonell. Spørsmålet er om dette fører til at persontilpasset medisin ikke regnes som helsehjelp, men som forskning, og hvilken betydning det i så fall kan ha for pasientenes rettigheter.

Nøkkelord: helseforskning, helseforskningsloven, helsehjelp, helsepersonell, helsepersonelloven, pasientog brukerrettighetsloven, persontilpasset medisin

Anne Kjersti Befring disputerte i mars 2019 med temaet rettslige perspektiver på persontilpasset medisin og er i dag førsteamanuensis ved Det juridiske fakultet ved UiO.

\section{Introduksjon ${ }^{1}$}

Persontilpasset medisin fører til endringer i hvordan helsetjenestetilbudet er organisert, finansiert og regulert. ${ }^{2}$ Flere land og internasjonale organisasjoner har strategier for å innføre persontilpasset medisin for å kunne behandle sykdommer som i dag ikke kan behandles effektivt. ${ }^{3}$

Innenfor helseretten er et grunnleggende spørsmål om persontilpasset medisin som inkluderer forskning og involverer forskere, kan regnes som helsehjelp i henhold til pasient- og brukerrettighetsloven $\S 1-3$ c. ${ }^{4}$ Persontilpasset medisin kan gi økte muligheter for å behandle sykdommer, ved at menneskets genetikk og biologi unders $\emptyset$ kes for å kunne stille presise diagnoser og for å tilpasse den medisinske

\footnotetext{
${ }^{1}$ Artikkelen bygger på prøveforelesning for graden ph.d. Takk til professor Aslak Syse som har gitt gode innspill til artikkelen.

${ }^{2}$ Anne Kjersti Befring, Persontilpasset medisin. Rettslige perspektiver, Oslo 2019, kap. 1 og 3.

${ }^{3}$ Sundheds- og ældreministeriet: Personlig medicin til gavn for patienterne, 2017-2010. ICPerMed ble etablert av EU og Europarådet i 2016. EU, Council conclusions on personalized medicine for patients, 2015 (2015/C 421/03); World Health Organisation (WHO), Priority Medicines Report, 2013.

${ }^{4}$ Pasient- og brukerrettighetsloven 2. juli 1999 nr. 63 (forkortes pbrl.).
} 
behandlingen etter denne kunnskapen. ${ }^{5}$ Brede genetiske undersøkelser og/eller avansert bildeteknologi gir omfattende data om mennesker som må analyseres og sammenlignes med data fra andre.

I denne artikkelen vurderes det regulatoriske skillet mellom helsehjelp og helseforskning når det utvikles nye former for diagnostikk og medisinsk behandling som innebærer forskning. I lovgivningen og i internasjonale konvensjoner er det et tydelig skille mellom reguleringer av helsehjelp og helseforskning, og legaldefinisjonen av «helsehjelp» i pbrl. § 1-3 c har vært oppfattet slik at den avgrenser mot helseforskning, som er regulert av helseforskningsloven. ${ }^{6}$ Spørsmålet her er om den rettslige tilnærmingen kan være en enten-eller-tilnærming når de faktiske endringene av medisinen innebærer en kombinasjon av helsehjelp og helseforskning. Videre undersøkes helsehjelpdefinisjonens betydning for lovvalg og rettigheter.

Første del av legaldefinisjonen av «helsehjelp» er en oppregning av hvilke handlinger som regnes som helsehjelp, og det må vurderes om et behandlingsforløp som inkluderer forskning, er omfattet av disse handlingene, jf. punkt 3. Den andre delen av helsehjelpdefinisjonen forutsetter at handlingene utføres av helsepersonell, jf. punkt 4. I punkt 5 vurderes det kort om legaldefinisjonen av helsehjelp er en rettslig skranke for pasientrettigheter i den forstand at definisjonen er bestemmende for lovens virkeområde.

\section{Bakgrunnen for legaldefinisjonen og sammenhenger i loven}

Helsehjelpdefinisjonen ble introdusert i pasientrettighetsloven som trådte i kraft i 2001.

Pasientrettighetsloven hadde som mål å samle rettigheter som var spredt flere steder i lovgivningen, for slik å styrke pasienters rettsstilling. ${ }^{7}$ I forbindelse med samhandlingsreformen i 2012 ble brukerrettigheter tatt inn i loven, og tittelen ble utvidet til pasient- og brukerrettighetsloven. ${ }^{8}$ I det første forslaget til ny pasientrettighetslov i NOU 1992: 8 ble helsehjelpbegrepet definert som

«enhver tjeneste som noen trenger på grunn av sykdom, skade, funksjonshemming eller graviditet, eller for å forebygge slike tilstander og som helsevesenet er nærmest til å gi». ${ }^{9}$

Begrunnelsen for å utvide denne definisjonen var blant annet at den skulle samsvare bedre med den vide definisjonen WHO benyttet, og unngå at «oppregningen av tilstander førte til at noen aktiviteter i helsetjenesten faller utenfor definisjonen». ${ }^{10} \mathrm{I}$ WHOs statutter fra 1948 defineres helse vidt som en tilstand av velvære: "A state of complete physical, mental and social well-being and not merely the absence of disease or infirmity». ${ }^{11}$ I Europadeklarasjonen om pasientrettigheter fra WHO i 1994 omtales helsehjelp som «medical, nursing or allied services dispensed by health care providers and health care establishments». ${ }^{12}$

Helsehjelpdefinisjonen har nær sammenheng med lovens formål, jf. pbrl. § 1-1, der det står at loven skal «bidra til å sikre befolkningen lik tilgang på tjenester av god kvalitet ved å gi pasienter og brukere rettigheter overfor helse- og omsorgstjenesten». ${ }^{13}$ Ifølge forarbeidene skal denne bestemmelsen «forklare

\footnotetext{
${ }^{5}$ Helsedirektoratet, Nasjonal strategi for persontilpasset medisin i helsetjenesten 2017-2021, 2016.

${ }^{6}$ Helseforskningsloven 20. juni 2008 nr. 44.

${ }^{7}$ Anne Kjersti Befring, Morten Kjelland og Aslak Syse, Sentrale helserettslige emner, Oslo 2016, kap. 1. Asbjørn Kjønstad og Aslak Syse, Helseprioriteringer og pasientrettigheter, Oslo 1992, s 233.

${ }^{8}$ Denne endringen skjedd i forbindelse med vedtakelsen av helse- og omsorgstjenesteloven 24. juni 2011 nr. 30 (forkortes hol.) som benytter begrepet «bruker». Se også Prop. nr. 91 L (2010-2011) kap. 48.

${ }^{9}$ NOU 1992: 8 Lov om pasientrettigheter, s. 37 flg.

${ }^{10}$ Høringsnotat - lov om pasientrettigheter, I-0888 B, juli 1997, s. 18.

${ }^{11} \mathrm{https} / / / \mathrm{www}$.who.int/about/who-we-are/constitution.

${ }_{12}$ WHO: A declaration on the promotion of patients' rights in Europe, Amsterdam, 28.-30. mars 1994.

${ }^{13}$ Formålet er utdypet i lovens forarbeider: Ot.prp. nr. 12 (1998-1999) del IV, kap. 12.
} 
bakgrunnen for den helsepolitikk loven bygger på, og [den] er tenkt å virke som en retningslinje for de ideelle mål som oppstilles i loven». ${ }^{14}$ Det er presisert at det følger av juridisk metode at formålsbestemmelsen har «verdi som rettskildefaktor, og har rettslig betydning som tolkningsmoment når innholdet i de enkelte bestemmelser skal bestemmes og anvendes i konkrete tilfeller [...]».

Når begrepet «helsehjelp»skal defineres, må det ses hen til hvor denne hjelpen gis. Helse- og omsorgstjenesten og apotek benyttes i loven for å definere rammen for aktiviteter som kan være helsehjelp, og personell som kan være helsepersonell, jf. hpl. § 3. I pbrl. § 1-3 d er «helse- og omsorgstjenesten» definert som:

«den kommunale helse- og omsorgstjenesten, spesialisthelsetjenesten, tannhelsetjenesten og private tilbydere av helse- og omsorgstjenester». ${ }^{15}$

De offentlige helsetjenestene er regulert i helse- og omsorgstjenesteloven, som gjelder kommunale tjenester, og i spesialisthelsetjenesteloven som regulerer de regionale og lokale helseforetakene. ${ }^{16}$ Private tjenester kan omfattes når det inngås avtaler med kommunen eller med det regionale helseforetaket som har ansvaret for spesialisthelsetjenesten. Når autorisert helsepersonell tilbyr helsetjenester uten slik avtale, er de likevel omfattet av helse- og omsorgstjenesten som «private tilbydere». Alternative behandlere som driver privat praksis, omfattes som hovedregel ikke.

I den opprinnelige definisjonen av «helsevesenet» ble det vist til «kommuners, fylkeskommuners og statens ansvar for å dekke pasienters behov». ${ }^{17}$ Denne tilnærmingen er snevrere da den ikke omfattet private helsetjenester. Det er presisert i gjeldende forarbeider at loven kommer til anvendelse uavhengig av om helsepersonellet er ansatt i privat eller offentlig virksomhet:

«når det gjelder rettigheter ift. informasjon, selvbestemmelse, medvirkning og journalinnsyn er det helsepersonell som er forpliktet til å sørge for oppfyllelse av rettighetene, ikke helsetjenesten som sådan. Det er likegyldig om helsepersonellet er ansatt i privat eller offentlig virksomhet.» ${ }^{18}$

Det er likevel en forskjell ved at helprivate tjenesteytere uten avtale ikke har plikter til å «sørge for» nødvendige helse- og omsorgstjenester.

\section{Helsehjelp og helseforskning ved persontilpasset medisin}

\subsection{Oppregning av oppgaver i helsehjelpdefinisjonen}

Etter pbrl. § 1-3 c er helsehjelp «handlinger som har forebyggende, diagnostisk, behandlende, helsebevarende, rehabiliterende eller pleie- og omsorgsformål». Den samme oppregningen benyttes til å definere om personell uten autorisasjon skal regnes som helsepersonell, jf. hpl. § 3 (3).

Gjennom henvisning til «mål» kan det legges til grunn at definisjonen er vid. Handlingene skal ha som mål å kunne påvirke helse-, pleie- og omsorgssituasjonen til en person. Det fremgår av forarbeidene at «abortinngrep, uttak av organer for transplantasjon og blodgiving omfattes», og at målet kan være

\footnotetext{
${ }^{14}$ Op. cit.

${ }^{15}$ Endringen er i liten utstrekning kommentert i forarbeidene. Omsorgsoppgaver som tidligere var regulert av sosialtjenesteloven, skulle reguleres som helsehjelp for å redusere «sosiale forskjeller» og oppnå en mer «likeverdig helsetjeneste», Prop. 91 L (2010-2011) s. 25-28. Pasientrettighetene skulle dessuten gjøres mer entydige og helhetlige. Dette formålet har først og fremst betydning gjennom at rettigheter til helsetjenester ble samlet i kap. 2-1.

${ }^{16}$ Spesialisthelsetjenesteloven 2. juli $1999 \mathrm{nr}$. 61 (forkortes shl.).

${ }^{17}$ I NOU 1992: 8.

${ }^{18}$ Høringsnotat - lov om pasientrettigheter, 1997.
} 
helsehjelp uavhengig av om det har oppstått sykdom, så lenge det er knyttet til behovet for ulike former for hjelp. ${ }^{19}$ Forebygging av sykdom er regnet som helsehjelp. Med «diagnostisering» menes tiltak som foretas basert på «pasientens sykehistorie og objektive funn» for å fastslå pasientens sykdom. ${ }^{20} \mathrm{I}$ angivelsen av at handlingen skal ha et diagnostisk eller behandlende formål, siktes det både til metoder for å stille diagnoser og til behandling. Aktiviteten må skje i helse- og omsorgstjenesten i vid forstand.

Persontilpasset medisin med formål om å stille en diagnose, å tilpasse medisinsk behandling eller å forebygge sykdom er omfattet av denne oppregningen. Det foretas imidlertid ingen tydelig avgrensning mot medisinsk forskning i persontilpasset medisin. Forskning har som regel et primært formål om å opparbeide ny kunnskap, ikke å gi helsehjelp. Det må derfor vurderes nærmere om hele eller kun deler av et pasientforløp som inkluderer forskning, er helsehjelp.

\subsection{Helsehjelp og forskning i et pasientforløp med persontilpasset medisin}

Når forskning blir en del av pasientforløpet, er utgangspunktet at denne aktiviteten er underlagt helseforskningsloven. Det kan likevel ikke utelukkes at aktiviteten også kan regnes som helsehjelp i henhold til pbrl. § 1-3 c.

Selv om lovgivningen tar utgangspunkt i et tradisjonelt behandlingsforløp som starter med at det stilles en diagnose som grunnlag for medisinsk behandling, og som avsluttes når pasienten har fått helsehjelpen, kan nye medisinske metoder være omfattet.

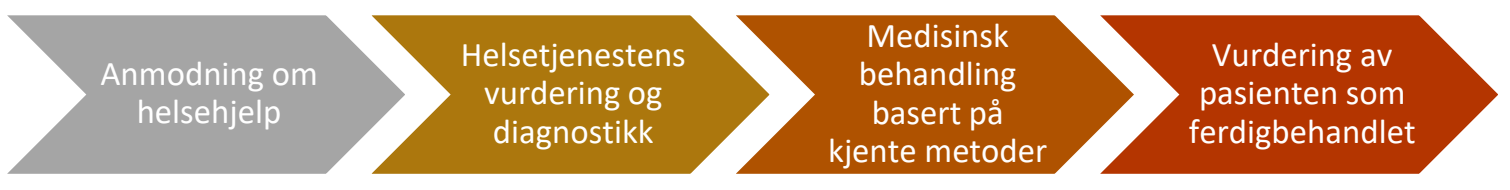

Figuren viser et ordinært pasientforløp

Et kjennetegn ved persontilpasset medisin er at det kan være uklart når helsehjelpen avsluttes, da det kan ta tid å opparbeide kunnskap, og at det kan være nødvendig å holde kontakten med pasienten ved ny kunnskap. Et pasientforløp med persontilpasset medisin kan beskrives som alle stadier i prosessen med kartlegging av genetikken, klinisk utprøvning og kunnskapsbasert helsehjelp, kommunikasjon med pasienten og behandling av det genetiske materialet.Dette kan innebære flere unders $\varnothing$ kelser underveis, og det oppstår spørsmål om hvilke plikter helsetjenesten kan ha til å «gå tilbake til pasienten», eventuelt også til pasientens slektninger, når det opparbeides viktig kunnskap av betydning for å kunne behandle sykdom. Disse spørsmålene behandles ikke nærmere her.

${ }^{19}$ Ot. prp. nr. 12 (1998-1999) kap. IV.

${ }^{20}$ Det kan også ha et forebyggende mål dersom det benyttes med sikte på å oppnå informasjon om bæreregenskaper, omtalt som prediktive genetiske undersøkelser, se biotl. § 5-1 (2). 

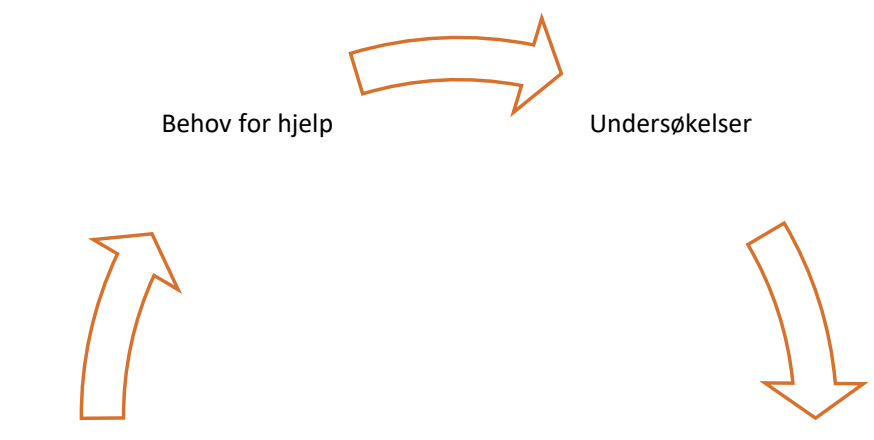
Kvalitetssikring og Klinisk utprøvning $\begin{array}{ll}\text { usikkerhet } & \text { av genetiske } \\ \text { varianter }\end{array}$

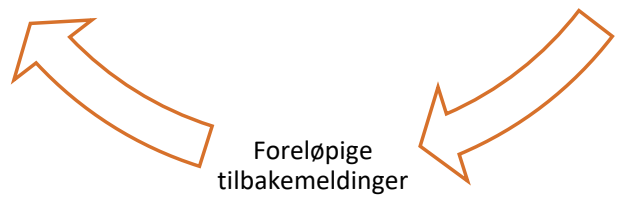

\subsection{Behandlingsforløp med persontilpasset medisin}

I den nasjonale strategien for persontilpasset medisin av 2016 er det en figur som viser hvordan klinisk utprøvning blir en del av pasientforløpet. ${ }^{21}$ I figuren er et ordinært pasientforl $\varnothing p$ framstilt i venstre halvdel. Til høyre er det skissert et pasientforløp som innebærer forskning, fremhevet med røde piler.
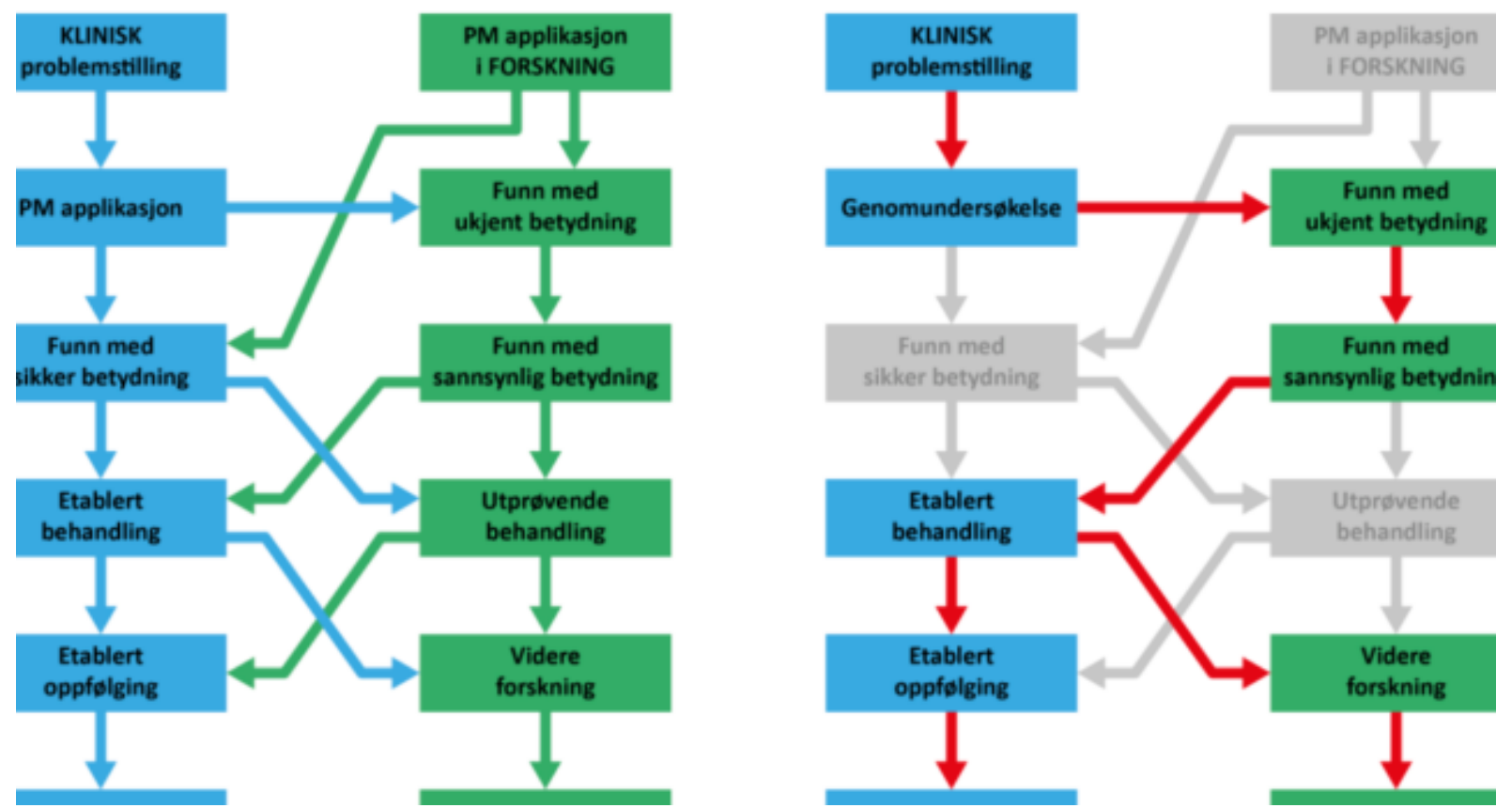

Et pasientforløp med persontilpasset medisin knyttet til for eksempel en ukjent form for immunsvikt påbegynnes med kartlegging av genetikken, noe som typisk gir både sikre og usikre genetiske funn. Deretter kan genomet (arvestoffet/DNA) eller genene til et menneske kartlegges, omtalt som henholdsvis

${ }^{21}$ Nasjonal strategi for persontilpasset medisin, 1. juni 2016: IS-2446, s. 16 flg. 
genomsekvensering og eksomsekvensering. ${ }^{22}$ Pasientens biologi og genetikk sammenlignes med eksisterende kunnskap, men det kan også måtte opparbeides ny kunnskap om hvilken betydning genetiske kjennetegn kan ha, noe som er forskning. Denne metoden er annerledes enn dagens inndeling av diagnoser i grupper og etter generelle kjennetegn. Kunnskapen som opparbeides, kan i seg selv ha begrenset overføringsverdi (som evidensbasert medisin) dersom det dreier seg om sjeldne genetiske varianter. $^{23}$

\subsection{Om det legale skillet mellom helsehjelp og helseforskning kan opprettholdes}

Det legale skillet mellom helsehjelp og helseforskning begrunnes i at behandlingsmetoder som ikke bygger på vitenskapelig kunnskap eller erfaringer, må underlegges særskilte regler som følge av at risikoen er høyere. Helsinki-deklarasjonen var den første internasjonale reguleringen av helseforskning og har hatt (og har) stor betydning globalt selv om den kun er veiledende. ${ }^{24}$ Biomedisinkonvensjonen er den første internasjonale konvensjonen som gjelder både medisinsk behandling og helseforskning, med egne regler for helseforskning i en tilleggsprotokoll. ${ }^{25}$ Helseforskningsloven bygger på Helsinki-deklarasjonen og viser til Biomedisinkonvensjonen. ${ }^{26}$

Helseforskning skal vurderes og gis forhåndsgodkjenning av en regional etikk-komité (REK) som vurderer risiko og andre sider av forskningen, jf. hfl. $\$ \S 9$ og 10. Risikobegrepet har en vid anvendelse i denne forbindelse. Konsekvensene av at det ikke gis tilbud om forskning, omfattes av denne vurderingen, for eksempel om det ikke prøves ut ulike medisiner på alvorlig syke pasienter med Covid-19-viruset. I denne sammenhengen er det aktuelt med persontilpasset medisin som baseres på genetiske undersøkelser av viruset og mennesket. ${ }^{27}$

Helsehjelpdefinisjonen kan oppfattes som en avgrensning mot helseforskning omfattet av helseforskningsloven under forutsetning av at det primære formålet med forskningen er å opparbeide medisinsk kunnskap. Dette kan belyses ved forsvarlighetsplikten som langt på vei forutsetter at det benyttes vitenskapelige metoder eller metoder basert på omfattende erfaring, jf. hpl. § 4 og shl. § 2-2. ${ }^{28}$ Denne rettslige standarden er dynamisk i den forstand at kravet må ses i sammenheng med omstendighetene og den faglige kunnskapen som foreligger. Når det foreligger lite kunnskap, kan det være nødvendig at pasienten blir forsøksperson for å kunne motta helsehjelp. Persontilpasset medisin innebærer at det primære formålet er å finne en effektiv behandling for pasienten, selv om det innebærer klinisk forskning. Helseforskningsloven har i liten grad tatt hensyn til denne situasjonen og at pasienter må ha i behold sine rettigheter når overgangen til helseforskning begrunnes i mulighetene for å gi helsehjelp.

Det er liten veiledning i pasient- og brukerrettighetsloven og helseforskningsloven om rettigheter i denne sammenhengen. Forskning er imidlertid regnet som en kjerneoppgave for sykehus, jf. shl. § 3-8, noe som kan benyttes som et argument for at det inngår i det medisinske behandlingstilbudet. I kommentarutgaver har kommentarene til helsehjelpdefinisjonen ikke omtalt klinisk forskning, noe som

${ }^{22}$ Befring (2019) kap. 3.

${ }^{23}$ Se dansk strategi 2017-2020, 4/13: kap. om etiske oppmærksomhedspunkter.

${ }^{24}$ WMA: Declaration of Helsinki - Ethical Principles for Medical Research Involving Human Subjects, Helsinki juni 1964.

${ }^{25}$ Konvensjon om beskyttelse av menneskerettighetene og menneskets verdighet i forbindelse med anvendelsen av biologi og medisin, konvensjon om menneskerettigheter og biomedisin, Oviedo 4. april 1997 (ETS 164).

${ }^{26}$ Helseforskningloven 20. juni 2008 nr. 44 (forkortes hfl.)

${ }^{27}$ Befring (2019) kap. 8.

${ }^{28}$ Helsepersonelloven 2. juli 1999 nr. 64 (forkortes hpl.). 
tyder på at forskning ikke har blitt vurdert som del av helsehjelpen. ${ }^{29}$ Reguleringer av forskning som del av pasienttilbudet har i liten grad blitt problematisert i forvaltningspraksis eller i juridisk teori. ${ }^{30}$

Når pasientbehandlingen i stadig større grad forutsetter forskning, er dette et argument for at skillet mellom forskning og helsehjelp ikke kan være så absolutt som inndelingen i ulike lover gir uttrykk for. Forskningen som inngår i persontilpasset medisin, skal primært føre til at pasienten får stilt en diagnose og får behandling, selv om ny medisinsk kunnskap også er en målsetting. De samme hensyn gjør seg gjeldende ved persontilpasset medisin som ved annen medisinsk behandling, og kan begrunne at det regnes som helsehjelp etter pbrl. § 1-3 c selv om det er innslag av forskning.

For det andre er ikke forskningen som inngår i persontilpasset medisin, tradisjonell helseforskning. Det benyttes en annen forskningsmetodikk enn den som er beskrevet i hfl.§ 4 a som «virksomhet som utføres med vitenskapelig metodikk for å skaffe til veie ny kunnskap om helse og sykdom». Ved persontilpasset medisin er det primært kunnskapen om den enkelte pasients genetikk som er målet, ikke generell kunnskap. En uttalelse i helseforskningslovens forarbeider avgrenser helseforskningslovens virkeområde, og kan være et argument for at persontilpasset medisin omfattes av helsehjelpbegrepet:

«Dersom formålet med den utprøvende behandlingen primært er å gi helsehjelp til en pasient, vil lovens regler ikke komme til anvendelse.» ${ }^{31}$

Persontilpasset medisin som klinisk utprøvning og helsehjelp er verken tradisjonell forskning eller tradisjonell helsehjelp, men har større likhetstrekk med ordinær helsehjelp.

For det tredje vil hensynet til pasienters forutsigbarhet være et argument for at persontilpasset medisin skal anses som helsehjelp, uavhengig av om det er innslag av klinisk utprøvning underveis i pasientforløpet. Målet om å ha en vid definisjon av helsehjelp skal bidra til at pasient- og brukerrettighetsloven gjelder. Det vises til uttalelsen fra Syse om at definisjonen av helsehjelp er «nærmest altomfattende i forhold til handlinger». ${ }^{32}$ Når innslaget av klinisk utprøvning «standardiseres» som del av pasientforløpet, er dette et argument for at det omfattes av helsehjelpdefinisjonen.

Konklusjonen er at persontilpasset medisin som tilbys i helsetjenesten, omfattes av helsehjelpdefinisjonen i pbrl. § 1-3 c selv om pasientforløpet innebærer innslag av forskning. Dette utelukker ikke at kliniske studier som denne helsehjelpen kan være del av, samtidig omfattes av helseforskningsloven. Samtidig innebærer dette at endringer i behandlingstilbudet ved innføring av persontilpasset medisin som inkluderer klinisk forskning, får betydning for innholdet i retten til nødvendig helsehjelp. Det kan ikke nødvendigvis avgrenses mot behandlingsmetoder med henvisning til at det inkluderer klinisk forskning. ${ }^{33}$

\section{Helsepersonell som del av helsehjelpdefinisjonen}

\subsection{Helsepersonell med autorisasjon og lisens og andre}

Den andre delen av legaldefinisjonen i pbrl. $§ 1-3 \mathrm{c}$ forutsetter at helsehjelp «utføres av helsepersonell».

Hvem som regnes som helsepersonell, er nærmere definert i hpl. § 3 og der inndelt i tre ulike kategorier, personell med autorisasjon og lisens, personell uten autorisasjon og lisens som gir helsehjelp,

\footnotetext{
${ }^{29}$ Syse har kommentert legaldefinisjonen i sin kommentarutgave uten å gå inn på medisinsk forskning, se Aslak Syse, Pasient- og brukerettighetsloven med kommentarer, 4. utg., Oslo 2015, kap. 1.

${ }^{30}$ Befring (2019) kap. 7, 8 og 11 tar opp noen problemsstillinger.

${ }^{31}$ Ot.prp. nr. 74 (2006-2007) s. 149.

${ }^{32}$ Aslak Syse, Juridisk betenkning vedr. enkelte spørsmål knyttet til helsetjenester ved bruk av moderne former for telekommunikasjon, 23. juli 2007 (til Helsedirektoratet), s. 10.

${ }^{33}$ Befring (2019) kap. 11.
} 
og elever og studenter. I tillegg til denne bestemmelsen kan personer som midlertidig er medhjelpere, regnes som helsepersonell, jf. hpl. § 5 .

Den første kategorien er helsepersonell med autorisasjon og lisens, jf. hpl. $\S 3 \mathrm{nr} .1$. I og med at helsepersonelloven er felles for alle grupper, er det oppregnet hvilke grupper dette gjelder i hpl. § 48 a.

Personer med begrenset autorisasjon (lisens), jf. hpl. § 49, omfattes. Denne bestemmelsen behandles ikke nærmere da det er klart at alle med autorisasjon eller lisens regnes som helsepersonell.

Mer uklart er det om teknologer, bioinformatikere og andre uten autorisasjon, og uten pasientkontakt, regnes som helsepersonell. I et pasientforløp med persontilpasset medisin kan personer med ulik fagbakgrunn og uten autorisasjon delta for å gi helsehjelp.

Det kan være nødvendig med teknologisk og annen kompetanse for å kunne tolke resultatet av genetiske undersøkelser. Bioinformatikere kan bistå med å benytte og tolke store datamengder, for eksempel strukturen i genene som undersøkes i mennesket eller kreftsvulster, og med sammenligninger av disse med genetiske varianter fra friske og syke. Bistanden omfatter å etablere dataverktøy.

Molekylærbiologer eller bioingeniører med særskilt kompetanse inkluderes i arbeidet med å vurdere om de genetiske variantene gir sykdom. Det kan være aktuelt å inkludere internasjonal eksperthjelp for å unders $\varnothing \mathrm{ke}$ om det finnes tilsvarende funn i andre land, eller for å sammenligne med internasjonale databaser. Dette kan Illustreres slik:
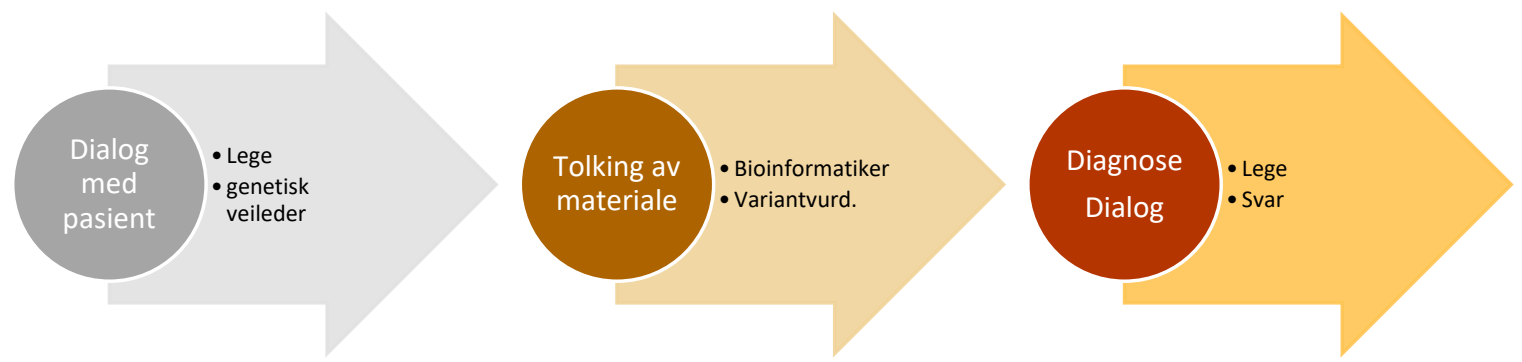

I et behandlingsforløp med persontilpasset medisin kan personer med ulik fagbakgrunn og uten autorisasjon delta for å gi helsehjelp, enten fordi det tildeles oppgaver fra helsepersonell eller ved at personell er ansatt for å ha en bestemt funksjon i forbindelse med persontilpasset medisin. Det vurderes først om disse personene kan vurderes som medhjelpere i henhold til hpl. § 5, deretter om de er regnet som helsepersonell i henhold til hpl. § 3 (1) nr. 2.

Det er en adgang for helsepersonell til å benytte medhjelpere under nærmere angitte betingelser i hpl. $\S$ 5. Medhjelpere i lovens forstand vil være personer som får tildelt oppgaver fra helsepersonell under veiledning og det er i denne sammenhengen de regnes som helsepersonell. Det er presisert i lovens forarbeider at helsepersonelldefinisjonen knyttes til utføringen av denne oppgaven som en kortvarig funksjonsbeskrivelse:

«Når det gjelder medhjelpere er disse å regne som helsepersonell, når de får tildelt oppgaver fra helsepersonell.» ${ }^{34}$

Medhjelperordningen innebærer at det benyttes personer som i utgangspunktet ikke har tilstrekkelig kompetanse for å utføre oppgavene på egen hånd. Dette fremgår forutsetningsvis av lovbestemmelsen, gjennom at det må være «forsvarlig ut fra oppgavens art, personellets kvalifikasjoner og den oppfølgning som gis». Medhjelperen er underlagt «helsepersonells kontroll og tilsyn». Helsepersonell som benytter en medhjelper, må dermed ha den kompetansen som medhjelperen i utgangspunktet ikke selv har.

Dette innebærer at denne bestemmelsen ikke kommer til anvendelse når helsepersonellet benytter personer med en annen kompetanse enn den helsepersonellet har, det vil si til å kompensere for egen manglende kompetanse. I lovens forarbeider er følgende presisert:

\footnotetext{
${ }^{34}$ Ot.prp. nr. 13 (1998-1999) s. 214 flg.
} 
«Man kan ikke overlate til andre å utføre oppgaver når man selv ikke har nødvendige faglige og formelle kvalifikasjoner innen det aktuelle området.» ${ }^{35}$

Dette innebærer at medhjelperordningen vil ha liten betydning når det benyttes teknologer og personer med annen spesialkompetanse fordi helsepersonell ikke har nødvendig kompetanse i forbindelse med persontilpasset medisin.

Konklusjonen er at medhjelperordningen i hpl. $§ 5$ ikke kommer til anvendelse når det benyttes ekspertkompetanse i forbindelse med persontilpasset medisin.

\subsection{Personer som gir helsehjelp i helse- og omsorgstjenesten, jf. hpl. § 3 (1) nr. 2 og}

3

De to neste kategoriene er personell som arbeider innenfor helse- og omsorgstjenesten og apotek, samt elever og studenter, jf. hpl. § 3 (1) nr. 2 og $3 .^{36}$ Denne utvidelsen kom med helsepersonelloven da helsepersonellbegrepet tidligere kun ble benyttet om autorisert (og offentlig godkjent) helsepersonell. ${ }^{37}$

De oppgavene det siktes til at personell må ha for å regnes som helsepersonell, er definert i hpl. § 3 (3), og likt med pbrl. §1-3 c, som aktiviteter som regnes som helsehjelp, se punkt 3 ovenfor. Det er tilsiktet at samme definisjon er benyttet begge steder, noe som fremgår av forarbeidene: «pasientrettighetsloven og helsepersonelloven bør ha samme angivelse av 'helsepersonell'». ${ }^{38}$

I pasient- og brukerrettighetsloven fører denne tilføyelsen til en nødvendig avgrensning, slik at helsehjelp fra personer utenfor helsetjenesten ikke omfattes av loven. I forarbeidene er det vist til at hjelp som gis fra foreldre, ikke skal regnes som helsehjelp etter loven, bortsett fra når det skjer etter instruksjon fra helsepersonell. ${ }^{39}$ Når samme tilføyelse ble tatt inn i hpl. § 3 (1) nr. 2, førte det imidlertid til en sirkeldefinisjon: «helsepersonell er [...] som er helsepersonell». Lovens system (at det er tre alternativer i § 3) og forarbeidene viser imidlertid at dette må vurderes som en inkurie. Departementet og stortingskomiteen poengterte at formålet var å utvide definisjonen av «helsepersonell», og samtidig å avgrense definisjonen:

«Den avsluttende delen i tredje ledd '... og som utføres av helsepersonell' er nødvendig for å avgrense dels mot handlinger som utføres leilighetsvis av en hvilken som helst person, og dels mot behandlingsvirksomhet som loven ikke tar sikte på å regulere.» ${ }^{40}$

Avgrensningen kan tolkes slik at det i loven er skilt mellom personer som gjør oppgaver i henhold til en konkret instruksjon i henhold til hpl. § 5, og som kun regnes som helsepersonell når oppgaven utføres, og

${ }^{35}$ Ot.prp. nr. 13 (1998-1999) s. 218.

${ }^{36}$ Begrepet «apotek» er definert i apotekloven 2. juni 2000 nr. 39, § 1-3 a.

${ }^{37}$ Etter at loven trådte i kraft, er det tatt inn en særregel for kommunehelsetjenesten som utvider definisjonen ytterligere, og som ikke behandles nærmere her. Helsepersonelldefinisjonen ble utvidet i 2012 til å gjelde alle ansatte i den kommunale helse- og omsorgstjenesten, jf. helse- og omsorgstjenesteloven $§ 2-1$, der det står at «personell som yter tjenester etter denne loven», skal regnes som helsepersonell. Denne endringen fører til at de som yter det som tidligere ble betegnet som sosiale tjenester, for eksempel overfor personer som bor i kommunale enheter, etter denne loven gir omsorgstjenester som fører til at de er å anse som helsepersonell. Prop. 91 L (20102011) s. 486.

${ }^{38}$ Ot.prp. nr. 12 (1998-1999), siste setning på s. 38.

${ }^{39}$ Ot.prp. nr. 12 (1998-1999) s. 127. I lovendring 21. desember 2000 nr. 127 og Innst. O. nr. 38 (20002001) kap. 2 fremgår det at departementet er klar over at det oppstår en sirkeldefinisjon. Se også Ot.prp. nr. 14 (2000-2001).

${ }^{40}$ Innst. O. nr. 38 (2000-2001) punkt 2.1 og Ot.prp. nr. 14 (2000-2001) s. 5-6. 
personell som i sin funksjon innenfor helse- og omsorgstjenesten er helsepersonell etter hpl. § 3 (1) nr. 2. Det vises til uttalelser i lovens forarbeider om utvidelsen av hvem som regnes som helsepersonell:

«Et virkeområde utfra funksjon i helsetjenesten - i tillegg til autorisasjon - anses likevel hensiktsmessig utfra hovedformålet med reguleringene, nemlig å bidra til kvalitet i helsetjenesten. [...] En slik utvidelse av virkeområdet vil kunne bidra til å dempe motsetninger ved at enhver med pasientrelaterte oppgaver anses som helsepersonell. Samtidig som flere yrkesutøvere ansvarliggjøres for sine handlinger/unnlatelser i behandlingssammenheng.» ${ }^{41}$

I forvaltningspraksis har personer uten autorisasjon blitt ilagt reaksjoner i henhold til helsepersonelloven. ${ }^{42}$ De to alternativene i hpl. § 3 (1) nr. 2 og 3 innebærer dermed en viktig utvidelse av hvem som regnes som helsepersonell. ${ }^{43}$

Det må vurderes nærmere om dette gjelder alle personer som deltar i et pasientforløp med persontilpasset medisin. I og med at de oppgaver som omfattes av oppregningen, er vide, blir definisjonen av helsepersonell tilsvarende vid. Det presiseres i forarbeidene at personell som «arbeider i andre tjenester, som for eksempel sosialtjenesten eller trygden», ikke regnes som helsepersonell. ${ }^{44}$

Som vist i punkt 2 og 3.1 ovenfor inneholder denne delen av helsepersonelldefinisjonen to elementer. At det utføres bestemte oppgaver oppregnet som helsehjelp, og at disse utføres innenfor en ytre ramme som er helse- og omsorgstjenesten og apotek. Med denne koblingen legges det opp til at det er etablert en behandlerrelasjon til en pasient. I forbindelse med persontilpasset medisin vil «genetiske veiledere» som arbeider i helse- og omsorgstjenesten helt klart regnes som helsepersonell i henhold til disse kriteriene. Det er mer tvilsomt om personell som ikke har pasientkontakt, skal regnes som helsepersonell. Ordlyden gir ikke i seg selv grunnlag for å utlede et vilkår om at personell har kontakt med pasienten. En uttalelse i forarbeidene viser riktignok til at personell som «ikke har kontakt med pasienter ikke omfattes av lovens første ledd punkt $2 \gg .{ }^{45}$ Som eksempler vises det imidlertid til rengjøringspersonale, transportører eller sjåfører, det vil si personell som ofte har pasientkontakt, men hvor kontakten ikke har betydning for helsetilbudet.

Andre steder i lovens forarbeider gis det eksempler på helsepersonell som ikke nødvendigvis har dialog med pasienten: for eksempel «medisinske fysikere i sykehus [...] eller andre enkeltpersoner som med spesiell kompetanse eller etter opplæring tildeles ansvar for pasienter eller pasientopplysninger». ${ }^{46} \mathrm{Et}$ argument i samme retning er at flere av gruppene med autorisasjon ikke nødvendigvis har pasientkontakt, for eksempel perfusjonister som betjener hjerte- og lungemaskiner, jf. hpl. § 48 a, (bokstav s).

Fra forvaltningspraksis er det dessuten eksempler på at helsepersonell gis disiplinærreaksjoner på bakgrunn av handlinger og unnlatelser uavhengig av om dette skyldes pasientkontakt, for eksempel dersom helsepersonell ikke har gitt nødvendig helsehjelp. ${ }^{47}$

Lovens system og uttalelser i forarbeidene viser imidlertid at det må foretas en avgrensning med hensyn til hvem som er helsepersonell. I forarbeidene uttales det at definisjonen av helsepersonell skal

${ }^{41}$ Høringsnotat - Lov om helsepersonell, I-0891 B, juli 1997, s. 10.

${ }^{42}$ HPN 2010/123.

${ }^{43}$ Anne Kjersti Befring og Bente Ohnstad, Helsepersonelloven. Kommentarutgave, Bergen 2019, kap. 1. Se lovendring 21. desember 2000 nr. 127.

${ }^{44}$ Ot.prp. nr. 13 (1998-1999) s. 215. Denne uttalelsen må vurderes i lys av den nye bestemmelsen i hol. $\S$ $2-1$.

${ }^{45}$ Ot.prp. nr. 13 (1998-1999) s. 215.

${ }^{46}$ Ot.prp. nr. 13 (1998-1999) s. 214 og 215.

${ }^{47}$ Statens helsetilsyn ila en advarsel 1 . november 2010 til en person som ikke hadde autorisasjon, men som arbeidet $\mathrm{i}$ helsetjenesten og som misbrukte sin tilgang til en død pasients bankkort til tyveri. Hun ringte banken og utga seg for å være pasienten for å få oppgitt koden. Helsetilsynet la til grunn at hun var omfattet av hpl. $\S 3 \mathrm{nr} .2$, selv om det i denne situasjonen ikke var pasientkontakt. 
være «hensiktsmessig ut fra intensjonen med loven og de enkelte bestemmelser om vedkommende personell er helsepersonell»:

«Formålet med lovreguleringen forutsetter at enhver som i sitt yrke undersøker, diagnostiserer, behandler eller på annen måte følger opp en pasient, må omfattes av lovens reguleringer. Dette foreslås gjennomført ved at loven i utgangspunktet gjelder for alt helsepersonell og at helsepersonell defineres utfra funksjon i helsetjenesten.» ${ }^{48}$

Dette taler for at alle som deltar i ulike sider av helsehjelpen, uavhengig av autorisasjon, er regulert:

«Komiteens flertall, medlemmer fra [...], viser til at definisjonene av helsepersonell etter denne loven innebærer en utvidelse i forhold til gjeldende rett [...] Begrunnelsen er at alle som gir helsehjelp innen helsetjenesten, bør omfattes av plikten til forsvarlighet og taushet om pasientinformasjon, og at tilsynsmyndighetene kan føre tilsyn med disse. På denne måte understrekes lovens hovedformål om pasientsikkerhet.» $^{49}$

Det fremheves at hensynet til kvaliteten på helsehjelpen og forsvarligheten begrunner en vid definisjon av helsepersonell slik at flere er omfattet av loven. ${ }^{50}$ Dette er samtidig er argument for at hensynet til pasientsikkerheten kan begrunne at personer som deltar i et pasientforløp med beslutninger og handlinger av betydning for pasienten, regnes som helsepersonell, uavhengig av om de har pasientkontakt. Med dette perspektivet kan det argumenteres for at definisjonen vil omfatte farmakologer, biometrister, ingeniører og molekylærbiologer som bidrar til persontilpasset medisin.

En vesentlig forskjell mellom denne definisjonen og medhjelperordningen i hpl. § 5 er at dette personellet er helsepersonell, uavhengig av om de er tildelt oppgaver av (annet) helsepersonell.

Konklusjonen er at personer som bidrar til helsehjelpen i forbindelse med persontilpasset medisin, regnes som helsepersonell selv om de ikke har autorisasjon eller pasientkontakt. Dette innebærer at personell som deltar i den medisinske behandlingen av pasienter i sykehus eller annen helsetjeneste, regnes som helsepersonell. Forutsetningen er at bidraget har direkte betydning for pasienten. Den vide definisjonen av helsepersonell fører til en vid definisjon av helsehjelp, jf. pbrl. § 1-3 c. Rettsvirkningene er at dette personellet kan ilegges reaksjonen advarsel i henhold til hpl. § 56, eller straff, jf. hpl. § 67, ved brudd på lovens plikter.

\section{Helsehjelpdefinisjonen og pasientrettigheter}

Helsehjelpdefinisjonen omfatter hele pasientforløpet i forbindelse med persontilpasset medisin, jf. konklusjonen i punkt 3 og 4 . Den som trenger øyeblikkelig eller nødvendig helsehjelp, har sine rettigheter $\mathrm{i}$ behold selv om det i helsehjelpen er innslag av klinisk forskning, jf. pbrl. § $2-1 \mathrm{a}-\mathrm{c} .{ }^{51}$ Det forutsettes at «nødvendighetsvilkåret» må oppfylles, og at det er et forsvarlig helsetilbud. ${ }^{52}$ I forvaltnings- og rettspraksis er det innholdet i $n \phi d v e n d i g$ helsehjelp som volder tvil, ikke helsehjelpdefinisjonen. Det innebærer at legaldefinisjonen av helsehjelp ikke er en begrensning for personers rettigheter i et pasientforløp med persontilpasset medisin. Legaldefinisjonen kan derimot være veiledende for om aktiviteten regnes som helsehjelp omfattet av pasient- og brukerrettighetsloven, eller helseforskning som

${ }^{48}$ Ot.prp. nr. 13 (1998-1999) s. 29 og 30.

${ }^{49}$ Innst. O. nr. 58 (1998-1999) s. 44, Ot.prp. nr. 13 (1998-1999) s. 27-31 og 214-215.

${ }^{50}$ Se vilkårene i hpl. § 48 (2) og Ot.prp. nr. 13 (1998-1999) s. 127-131.

${ }^{51}$ Rettigheter må ses i sammenheng med plikter til å tilby tjenester, se Befring (2019) kap. 1, 8 og 11.

${ }^{52}$ Lovbestemmelsene inneholder ulike prosessuelle og materielle reguleringer mellom фyeblikkelig og $n \emptyset d v e n d i g$ helsehjelp. Øyeblikkelig hjelp skal gis mer eller mindre umiddelbart, og plikten inntrer når helsehjelpen er påtrengende nødvendig, jf. første ledd i pbrl. § 2-1 a og b. 
ikke reguleres av denne loven, jf. punktene 3 og 4 . I tillegg til helsehjelpbegrepet må det tas stilling til innholdet i nødvendighetsvilkåret, altså hva som anses å være «nødvendig» helsehjelp. Slik nødvendighetsvilkåret er formulert, kan det foreligge en rettighet som en konsekvens av at det ikke finnes andre metoder for å kunne stille en riktig diagnose. ${ }^{53}$ Det å stille kvalitative krav kan neppe vurderes som en begrensning av pasientrettigheter. ${ }^{54}$

Syse har uttalt om helsehjelpdefinisjonen og helsepersonelldefinisjonen at «ingen av de to definisjonene var ment å stå på 'egne ben'». De skulle fungere som en form for hjelpebegreper i sammenheng med andre og mer sentrale definisjoner for å avgrense virkeområdet til de to lovene. ${ }^{55}$ Definisjonen av helsehjelp må ses i sammenheng med lovens virkeområde og andre legaldefinisjoner, for å kunne ta stilling til hvilken betydning den har for rettigheter.

En begrensning vil følge av hvem som påberoper seg rettigheter. I pasient- og brukerrettighetsloven er det i utgangspunktet kun personer med pasientpretensjoner som vil være «pasienter». Begrepet pasient er definert som «en person som henvender seg til helse- og omsorgstjenesten med anmodning om helsehjelp, eller som helse- og omsorgstjenesten gir eller tilbyr helsehjelp i det enkelte tilfelle», jf. pbrl. § 1-3 a. I det opprinnelige lovforslaget fra departementet var det flere begrensninger i pasientbegrepet. ${ }^{56}$ Stortinget utvidet definisjonen til også å omfatte personer som ber om helsehjelp. ${ }^{57}$ Dette omfatter personer som ikke har blitt pasienter, men som venter på å få helsehjelp. Pasientrettigheter omfatter også personer som har vært pasienter og som blant annet ber om informasjon, innsyn i journal, jf. pbrl. § 5-1. ${ }^{58}$

Loven inneholder også rettigheter til informasjon etter at behandlingen er avsluttet, jf. pbrl. § 3-2 (7), og rettigheter til å klage, jf. pbrl. § 7-2. Det kan også være rettigheter som skal beskytte den enkelte fra å bli pasient, og for nærmeste pårørende..$^{59}$ Begrepet pasientrettigheter benyttes derfor vidt om ulike former for rettigheter, av prosessuell og materiell karakter, og om mer enn helsehjelp.

Pasientbegrepet er derfor ikke konsekvent når det gjelder rettigheter, i likhet med begrepet helsehjelp. Rettighetene i pasient- og brukerrettighetsloven kan dessuten omfatte flere enn pasienter, blant annet pasientens nærmeste pårørende eller foreldre.

Så langt har det vært liten usikkerhet om innholdet i helsehjelpdefinisjonen når innholdet i rettigheter diskuteres. Denne artikkelen viser at det er nødvendig å revurdere skillet mellom helsehjelp og helseforskning som en konsekvens av den medisinskteknologiske utviklingen. De faktiske endringene av medisinen fører til spørsmål om innholdet i rettigheter uavhengig av om persontilpasset medisin omfattes av helsehjelpbegrepet, og av om rettigheter kan utledes av annen lovgivning. Utover å være en del av lovens vide virkeområde og et grunnlag for lovvalg vil helsehjelpbegrepet ha begrenset betydning for å fastlegge innholdet i rettigheter. ${ }^{60}$

Plikter for staten, helsevirksomheter og helsepersonell som er regulert $\mathrm{i}$ andre lover enn pasient- og brukerrettighetsloven, kan være et grunnlag for å fastlegge innholdet i rettigheter. Rettigheter kan utledes på et bredere grunnlag ved både å analysere plikter og rettigheter, og pasientens muligheter for å klage $\mathrm{i}$ henhold til pbrl. $\S \S 7-2$ flg. og annen lovgivning, eller andre former for håndhevelse. ${ }^{61}$ Helsepersonellets

${ }^{53}$ Befring (2019) kap. 11.1.

${ }^{54}$ Befring (2019) kap. 7.2 og 11.3, der det drøftes om retten til nødvendig helsehjelp kan omfatte kliniske forsøk.

${ }^{55}$ Aslak Syse, Juridisk betenkning vedr. enkelte spørsmål knyttet til helsetjenester ved bruk av moderne former for telekommunikasjon, 23.07.07, s. 10.

${ }^{56}$ Ot.prp. nr. 10 (1998-1999).

${ }^{57}$ Innst. O. nr. 91 (1998-99) s. 16,

${ }^{58}$ Befring deler inn i fire kategorier (Helse- og omsorgsrett, Oslo 2017, kap. 1). Warberg deler inn i en alminnelig og spesiell del, Lasse Warberg, Norsk helserett, Oslo 2011, s. 19. Se Asbjørn Kjønstad, Helserett. Pasienters og helsearbeideres rettsstilling, 2. utg., Oslo 2007, s. 32.

${ }^{59}$ Syse (2015) kap. 1.3. I henhold til loven kan narmeste pårørende, jf. pbrl. § 1-3 b, ha rettigheter.

${ }^{60}$ Høringsnotatet s. 18 og 19.

${ }^{61}$ Ot.prp. nr. 12 (1998-1999), merknaden til § 1-1. Retten til nødvendig og forsvarlig helsehjelp i pbrl. § 2-1 a-c og § 1-1 må for eksempel ses i lys av plikten til forsvarlig helsehjelp i hpl. §§ 4 og 16 og 
plikt til å utøve forsvarlig helsehjelp i hpl. § 4 har betydning for hvordan nødvendighetsvilkåret i pbrl. § 2-1 a-c vurderes, og ligger til grunn for rettigheter til pasientskadeerstatning ved «svikt», jf. pasientskadeloven § 2 (1) a jf. § 1 (1) c. ${ }^{62}$ Pliktene for de regionale helseforetakene og kommunene til å «sørge for» nødvendige tjenester må ses i sammenheng med innholdet i nødvendighetsvilkåret, jf. shl. § 2-1. Statens overordnede plikt til å tilby helsetjenester og å ivareta befolkningens helse, samt å beskytte befolkningen mot sykdommer, har betydning for rettigheter som omfattes av flere lover. ${ }^{63}$ Dette kan omfatte plikter til å tilby persontilpasset medisin til befolkningen og andre medisinske metoder basert på ny kunnskap. Helsehjelpdefinisjonen dekker således ikke alle aktiviteter som kan forventes, og som har betydning for helsetilbudet $\mathrm{i}$ helsetjenesten.

\section{Oppsummerende vurderinger}

Konklusjonen er at et behandlingsforløp med persontilpasset medisin omfattes av helsehjelpdefinisjonen i pbrl. § 1-3 c, selv om det innebærer innslag av forskning og av personer som ikke har autorisasjon som helsepersonell. Det utelukker ikke at også helseforskningsloven kan komme til anvendelse. Legaldefinisjonen av «helsehjelp» vil i denne sammenhengen ikke representere en rettslig skranke for pasientrettigheter. Helsehjelpbegrepet gir i seg selv lite veiledning når det gjelder å bestemme i hvilken grad rettigheter i pasient- og brukerrettighetsloven kommer til anvendelse ved persontilpasset medisin. Definisjonen har betydning som en angivelse av lovens saklige virkeområde og bidrar til å avgrense retten til «nødvendig helsehjelp». Innholdet i den rettslige standarden «nødvendig» helsehjelp må tolkes utfra pasientens behov og tilgangen på nye medisinske metoder som persontilpasset medisin.

Dette innebærer at helsehjelpdefinisjonen ikke kan avgrenses mot helseforskning når formålet er å stille en diagnose eller å behandle en pasient.

Innføringen av persontilpasset medisin kan være et argument for at flere grupper gis autorisasjon. Autorisasjonsordningen kan gi økt forutsigbarhet om kvalifikasjonene til grupper som skal bidra i pasientbehandlingen. ${ }^{64}$ Helsepersonellnemnda har gått langt $\mathrm{i}$ å hevde at autorisasjonsordningen skal «garantere at helsepersonellet har de nødvendige faglige kvalifikasjoner og tilfredsstiller krav til atferd slik at allmennhetens tillit til helsetjenesten og helsepersonellet ikke krenkes». ${ }^{65}$ Et argument for at flere gis autorisasjon, følger også av de uttalte formålene i forarbeidene om å plassere det rettslige ansvaret direkte. ${ }^{66}$ Ved innføringen av persontilpasset medisin kan det være nødvendig å definere nye grupper og kompetansekrav for å skape forutsigbarhet om hvilken kompetanse som følger med nye titler, jf. hpl. §

74. Denne forutsigbarheten kan være viktig for både arbeidsgivere som ansetter personer, og for befolkningen som blir behandlet. De nye utfordringene når det gjelder kompetanse og behovet for kontinuerlig etterutdanning, kan være et argument for «resertifisering» knyttet til spesialistgodkjenninger, jf. hpl. $§ 51 .^{67}$

Denne artikkelen viser at utviklingen av medisinen gir nye rettsspørsmål om legaldefinisjoner, og utfordrer skillet mellom helsehjelp og helseforskning i lovgivningen. Det bør tydeliggjøres at helsehjelpbegrepet også omfatter persontilpasset medisin med innslag av forskning, forskere og

shl. § 2-2. Konfidensialitetsvernet må ses på bakgrunn av taushetsplikten i hpl. § 21 og pjl. § 15, og unntak fra denne plikten i hpl. $\S 22 \mathrm{flg}$.

${ }^{62}$ Pasientskadeloven 15. juni 2001 nr. 53.

${ }^{63}$ Befring (2019) kap. 11.2.

${ }^{64}$ I bioteknologilovens forarbeider ble det foreslått at autorisasjonsordningen bør videreutvikles, se Innst. S. nr. $238(2001-2001)$ s. 20.

${ }^{65}$ HPN 2010-21.

${ }^{66}$ Ot.prp. nr. 13 (1998-1999) s. 215.

${ }^{67}$ I shl. § 3-10 ligger det et ansvar for etterutdanning og opplæring. 
teknologer. Til sammenligning kan det nevnes at den danske loven på dette punktet er endret. ${ }^{68} \mathrm{I}$ Sundhedsloven avsnitt 4, § 13, er pasientenes rettsstilling ikke knyttet til begrepet helsehjelp eller en oppregning av hva dette innebærer, men til at det «udføres sundhedsfaglig virksomhed». Betegnelsen «sundhedsfaglig virksomhed» kan etter sin ordlyd omfatte persontilpasset medisin som inkluderer klinisk forskning.

${ }^{68}$ Den danske pasientrettighetslov som ble vedtatt i 1998 (lov om patienters retsstilling (lov nr 482 af 01/07/1998), definerte «behandling» på samme måte som det norske helsehjelpbegrepet i § 3 , som «undersøgelse, diagnosticering, sygdomsbehandling, genoptræning, sundhedsfaglig pleje og sundhedsfaglige forebyggelsestiltag over for den enkelte patient». Denne loven ble erstattet $\mathrm{i}$ 2004 av Sundhedsloven (2994/LSF 74). 